\title{
Психологічне дослідження особистості як суб”єкта спортивної діяльності
}

\author{
Валентина Воронова, Тетяна Петровська, \\ Вікторія Ковальчук, Ірина Смоляр
}

Національний університет фізичного виховання і спорту України, Київ, Україна

\begin{abstract}
Анотація. Розглянуто наукові дослідження співробітників кафедри психології і педагогіки Національного університету фрізичного виховання і спорту України, присвячені вирішенню ного виду спорту психологічних якостей спортсмена, що забезпечує його становлення в спорті як особистості і суб'єкта. Мета. Визначити специффіку прояву психологічних особливостей особистості спортсмена і тренера як суб'єктів спортивної діяльності. Методи. Аналіз науково-методичної літератури та даних мережі Інтернет, анкетування, експертна оцінка, методи психологічної діагностики, контент-аналіз, метод семантичного диференціалу. $P e-$ зультати. У ході дослідження виявлено, що психологічні особливості проявів особистості спортсменів та тренерів як суб'єктів спортивної діяльності сприятимуть цілеспрямованому формуванню у спортсменів психологічних якостей, які допоможуть досягненню успіхів у тренувальній і змагальній діяльності. Тренерам дадуть можливість успішно управляти процесом підготовки, враховуючи необхідний рівень розвитку науково обгрунтованих профеесійних якостей спортсменів.

Ключові слова: тренер, спортсмени, суб'єкт спортивної діяльності, лідерство, гендерні особливості, самооцінка, емоційне вигорання.

\section{Valentyna Voronova, Tetiana Petrovska, Viktoria Kovalchuk, Iryna Smoliar}

\section{PSYCHOLOGICAL STUDY OF PERSONALITY AS A SUBJECT OF SPORTS ACTIVITY} важливого завдання психології спорту - переходу в роботі тренерів від настанови на досягнення максимального результату до визначення розвитку і стабілізації необхідних для кож-

Abstract. The scientific researches of the staff of the Psychology and Pedagogy Department of the National University of Physical Education and Sport of Ukraine devoted to solving the important task of sports psychology - the transition in the work of coaches from the instruction to achieve the maximum result to determination of the development and stabilization of the psychological qualities of the athlete necessary for each sports event, which ensures his formation in sport as a personality and a subject have been addressed. Objective. To determine the specifics of manifestating psychological features of the personality of the athlete and coach as subjects of sports activities. Methods. Analysis of scientific and methodological literature and data of the Internet, questionnaires, expert assessment, methods of psychological diagnosis, content analysis, semantic differential method. Results. The study found that the psychological characteristics of manifesting the personality of athletes and coaches as subjects of sports activities will contribute to the purposeful formation of athletes' psychological qualities that will help to achieve success in training and competitive activities. Coaches will get the opportunity to successfully manage the training process with account for the required level of development of scientifically sound professional qualities of athletes.

Keywords: coach, athletes, sports activity subject, leadership, gender features, self-assessment, burnout.
Voronova V, Petrovska T, Kovalchuk V, Smoliar I. Psychological study of personality as a subject of sports activity. Theory and Methods of Physical education and sports. 2020; 2: 116-123

DOl: 10.32652/tmfvs.2020.2.116-123
Воронова В, Петровська Т, Ковальчук В, Смоляр І. Психологічне дослідження особистості як суб'єкта спортивної діяльності. Теорія і методика фрізичного виховання і спорту. 2020; 2: 116-123 DOI: 10.32652/tmfvs.2020.2.116-123
Вступ. Наукові дослідження 3 питань психологічної підготовки спортсменів на кафедрі психології і педагогіки Національного університету фрізичного виховання і спорту України (НУФВСУ) планомірними стають 3 1959 р., коли кафедру очолив М. Р. Богуш. Про це свідчать наявні матеріали, що відображають окремі аспекти спортивної психології в публікаціях того часу [23, 24, 27, 28]: психологічні особливості засвоєння вправ гімнастики; чуттєві відмінності розпізнавання спортсменами основних елементів сили; розвиток слухової чутливості і спеціалізованих сприймань у велосипедистів-шосейників (І. М. Онищенко); особливості запам'ятовування елементарних рухів, залежно від форм їх демонстрації; явища післядії в зоровому і руховому аналізаторах і їх роль у взаємодії під час сприйняття рухів (М. Р. Богуш); роль зорового і рухового контролю в ефективності виконання кидків м'яча, особливості чуттєвого розрізнення елементів швидкісно-силової витривалості спортсменів-ігровиків (Л. Й. Валігура); чуттєве розрізнення спортсменами елементів швидкісно-силової витривалості і швидкості (В. А. Федченко); сприйняття легкоатлетами елементів рухової структури стрибків (В. В. Клименко); оптимізація психічних станів спортсмена 3 урахуванням їхніх індивідуально-типологічних особливостей (М. П. Тішин). Експериментальні дослідження перейшли на більш високий статистично якісний рівень, коли в 1956-1958 рр. М. Р. Богушем було розроблено ряд інструментальних методів, що дозволило під час психологічного аналізу фрізичних вправ фріксувати зміни в амплітуді, фрормі, швидкості і силі рухів і дій, які виникають під час зміни психологічної структури дії.

у цей період наукові дослідження стосуються психологічних проблем підготовки і розвитку суб'єктів спортивно-педагогічної діяльності у сфрері фрізичного виховання і спорту; психолого-педагогічних особли- 
востей занять ффізичною культурою і спортом молоді; міжособистісних особливостей взаємин спортсменів; проблем занять спортом різних вікових груп; патопсихологічних змін у структурі особистості спортсмена; психологічних особливостей фізичного виховання дітей 3 відхиленнями в рівні здоров'я; зовнішніх фракторів, що обумовлюють рівень психічного стану тренера і психолого-педагогічних чинників оптимізації змагальної діяльності спортсменів в ігрових видах спорту. В таких дослідженнях обов'язково передбачалося, що психологічна підготовка в спорті, на відміну від інших видів підготовки, повинна здійснюватися постійно, де б не перебував і чим би не займався спортсмен: у період тренувальних або змагальних навантажень, відновлювальних заходів, удосконалення знань на тактичних заняттях, відпочинку, фрормального або неформального спілкування з товаришами по команді, тренерами, друзями. Ці напрями витікають з розуміння та визнання значення впливу психологічної підготовки на всі складові життєдіяльності спортсмена, коли в разі ігнорування будь-якої з них знижується ефективність роботи іншої.

Мета дослідження - визначення специффіки прояву психологічних особливостей особистості спортсмена та тренера як суб'єктів спортивної діяльності.

Методи дослідження: аналіз науково-методичної літератури та даних мережі Інтернет, анкетування, експертна оцінка, соціометрія, методи психологічної діагностики, контентаналіз, Q-сортування, метод семантичного дисреренціалу, методи математичної статистики.

Результати дослідження та їх обговорення. Наукові дослідження в рамках теми «Технології психологопедагогічного супроводу та розвитку суб'єктів спортивної діяльності» кафедри психології і педагогіки НУФВСУ присвячені вирішенню важливого завдання психології спорту - переходу в діяльності тренерів від настанови на досягнення максимального результату до визначення, розвитку і стабілізації необхідних для кожного конкретного виду спорту психологічних якостей спортсмена, що забезпечує перш за все його становлення в спорті як особистості і як суб'єкта.

Детальний аналіз сучасних досліджень стосовно такого важливого питання в спорті, як соціально-психологічні аспекти діяльності спортсменів, змушує констатувати, що вони вивчені ще недостатньо, або зводяться до рекомендацій та не базуються на наукових даних, оскільки виходять із емпіричних знахідок тренера, що викликає велику кількість запитань і проблем [34]. Зокрема, в ракурсі соціально-психологічних досліджень проблематика гендерних розходжень лідерства залишається поза фокусом уваги фрахівців: тренерів, педагогів, спортивних психологів [35].

Здійснивши необхідні теоретичні дослідження, І. І. Смоляр зауважує, що певна кількість проведених на сьогодні досліджень як в ігрових, командних, так і в багатьох інших видах спорту, спрямована на вивчення лідерських якостей спортсмена [34]. Основний висновок, до якого приводять наявні наукові матеріали, це те, що відсутність лідера найчастіше прирікає навіть висококваліфріковану команду на програш, оскільки він у спортивній команді - це головна особистість (після тренера), яка очолює групу і веде її до досягнення мети, при цьому активно взаємодіючи з усіма спортсменами [10-12, 18, 37].

Детальне вивчення питання лідерства у спортивних командах вказує на необхідність пошуку диференційованого підходу до індивідуалізації підготовки чоловіків і жінок у ігрових видах спорту, вивчення властивостей особистості лідерів (ділового та експресивного) [1, 3, 12, 13, 15].

Не менш значущу роль у поведінці лідера й його статусі відіграє спрямованість особистості та особистісні характеристики, які визначають сферу діяльності (ділову й емоційну) спортсмена в команді, причому виразність певних характеристик значною мірою пов'язана зі статусом і впливом на інших членів команд. Дослідження, спрямовані на вирішення цієї проблеми, дозволили порівняти структурну організацію чоловічих і жіночих команд 3 гандболу одного рівня розвитку; визначити особливості лідерства в чоловічих і жіночих командах; вивчи- ти особливості лідера чоловіка й лідера жінки у групах, що складаються із представників однієї статі; порівняти чоловічі та жіночі спортивні команди, зокрема особливості лідерів чоловіків і жінок у діловій і емоційній ссрері у процесі їхньої підготовки $[6,36]$. Отримані дані характеризують особистісні особливості, властиві спортсменам і спортсменкам, які мають у гандбольній команді високий і низький статус, а також особистісні прояви гандболістів і гандболісток, що є основою їхнього статусу в групі. Було доведено, що феномен лідерства в чоловічому й жіночому колективі розрізняється за певними ознаками (як і лідери чоловіки від лідерів жінок) [34]. При цьому, чим вище їх положення в групі, тим більш значущі розходження між ними (спортсмен-спортсменка) та іншими спортсменами.

Виявлено специфрічні для спортсменів і спортсменок особистісні характеристики, які властиві жінкам чоловікам відповідно у жіночих і чоловічих колективах (табл. 1). Проведення кореляційного аналізу дозволило встановити взаємозв'язок лідерського статусу та гендерних особливостей спортсмена та спортсменки в команді - чим більше у спортсменки виражена маскулінність (тенденція до чоловічої поведінки), тим вищою буде її позиція в групі.

Серед багатьох важливих психологічних особистісних властивостей спортсмена саме ступінь адекватност самооцінки може характеризувати рівень адаптації його психіки до навантажень тренувальної та змагальної діяльності. Це проявляється в успішності і вдоволеності спортсменом своїми результатами [19]. Тому адекватну самооцінку у спортсменів можна вважати одним з факторів, що впливають на ефективність їхньої змагальної діяльності. Огляд наукової літератури свідчить про те, що на сьогодні відсутні розробки, присвячені дослідженню самооцінки хокеїстів високого класу і методів впливу на рівень її прояву, хоча вивчення взаємозв'язку самооцінки й ефективності змагальної діяльності хокеїстів являє собою цікавий і перспективний напрям психології спорту, тому дослідження 
Т а б л и ц я 1. Характеристики особистості спортсменів, які корелюють с діловим і емоційним типом лідерства (гандбол)

\begin{tabular}{|c|c|c|}
\hline \multirow[b]{2}{*}{ Характеристика особистості } & \multicolumn{2}{|c|}{ Коефіціент кореляції (r) } \\
\hline & $\begin{array}{c}\text { діловий тип } \\
\text { лідерства }\end{array}$ & $\begin{array}{l}\text { емоційний тип } \\
\text { лідерства }\end{array}$ \\
\hline \multicolumn{3}{|l|}{ Чоловіки, n = 12} \\
\hline Стаж в команді, років & $0,62^{*}$ & $0,72^{* *}$ \\
\hline Іінтроверсія, бал & $0,65^{\star}$ & $0,58^{\star}$ \\
\hline Залежність, бал & $0,62^{*}$ & $0,73^{\star *}$ \\
\hline Лідерські якості, ранг & $0,81^{* *}$ & 0,53 \\
\hline Гіперлідерство, бал & $-0,60^{*}$ & $-0,20$ \\
\hline Ііндивідуалізм, бал & $0,73^{*}$ & 0,49 \\
\hline Вік, років & 0,42 & $0,72^{\star *}$ \\
\hline «Прийняття боротьби», бал & 0,23 & $0,66^{*}$ \\
\hline Домінування, бал & 0,37 & $0,61^{*}$ \\
\hline Прямолінійність, бал & 0,50 & $0,62^{*}$ \\
\hline Скептичність, бал & 0,56 & $0,74^{* *}$ \\
\hline \multicolumn{3}{|l|}{ Жінки, n = 15} \\
\hline Лідерські якості, ранг & $0,93^{\star *}$ & $0,68^{*}$ \\
\hline Андрогенність, бал & $-0,64^{*}$ & $-0,68^{*}$ \\
\hline Сила волі, бал & $0,68^{*}$ & $0,62^{*}$ \\
\hline Товариськість, бал & $0,59^{*}$ & $0,57^{\star}$ \\
\hline Вік, років & $0,81^{* *}$ & 0,22 \\
\hline Спортивний стаж, років & $0,80^{*}$ & 0,19 \\
\hline Ригідність, бал & $0,58^{*}$ & 0,49 \\
\hline Їндивідуалізм, бал & $0,65^{*}$ & 0,26 \\
\hline Сензитивність, бал & 0,43 & $0,62^{*}$ \\
\hline Тенденція до афіліації, бал & 0,54 & $0,60^{*}$ \\
\hline Нетовариськість, бал & $-0,27$ & $-0,63^{*}$ \\
\hline Їнтернальність в сімейних стосунках, стен & $-0,54$ & $-0,59^{*}$ \\
\hline
\end{tabular}

Примітки: * - коесріцієнт кореляції статистично значущий на рівні $\mathrm{p}<0,05$; ** - коесріцієнт кореляції статистично значущий на рівні $p<0,01$

А. П. Міхнова були спрямовані на всебічне вивчення цієї проблеми [26].

Низька самооцінка спортсмена може бути обумовлена багатьма причинами: вона може бути сформована в дитинстві через недоброзичливе або надмірно критичне ставлення старших, могла розвинутися у дитини через погану успішність у школі або насмішки однолітків. Показники приватних самооцінок спортсмена не завжди стабільні, що можна розглядати як механізм, який забезпечує саморегуляцію його особистості в умовах, що змінюються, тренувальної та змагальної діяльності [21].

Проведене експертне опитування дало можливість визначити значущі сторони підготовленості та особистісні якості, які використані у ході дослідження самооцінки хокеїстів. Вказані складові у вирішенні завдань дослідження були систематизовані й умов- но розподілені на три відносно самостійні групи [26]:

- самооцінка рівня фізичної підготовленості та здоров'я, куди віднесено самооцінку хокеїстами рівня розвитку рухових якостей: сили, швидкості, координаційних здібностей, гнучкості та витривалості, а також загальну самооцінку свого фізичного стану і здоров'я;

- самооцінка рівня техніко-тактичної підготовленості; оцінка технікотактичних дій спортсменів (техніка пересування на майданчику, точність виконання кидків по воротах) та власний рівень спортивної майстерності;

- самооцінка рівня психологічної підготовленості. До значущих психологічних властивостей, які увійшли до групи, було віднесено: самовладання, концентрація уваги, швидкість реакції, рівень розвитку пам'яті, здатність до антиципації (передбачення майбутньої події), стресостійкість, впевненість у своїх силах, варіативність мислення, оптимізм, цілеспрямованість.

Результати математичних процедур під час аналізу значущих сторін підготовленості та особистісних якостей, використаних у ході дослідження самооцінки хокеїстів, дозволили констатувати таке [26].

За шкалою «Силові здібності» практично у всіх обстежених хокеїстів відмічається високий рівень самооцінки. Середній рівень самооцінки в групі становить 76,25 $\pm 11,61$, рівень домагань $-88,75 \pm 9,03$, а середній рівень цільового відхилення $-12,05 \pm 6,05$, який свідчить, що для групи в цілому характерний розвинений механізм визначення мети й уміння ставити реально здійсненні цілі.

Високий рівень самооцінки і домагання хокеїстів за шкалою «Силові здібності», на наш погляд, обумовлений винятковою значущістю цієї якості в структурі їхньої фізичної підготовленості. Не применшуючи значущості і рівня розвитку інших рухових якостей, роль силових здібностей в хокеї складно переоцінити. Серед більшості командних ігрових видів спорту (футбол, баскетбол, волейбол, гандбол), саме в хокеї прояв силового компонента відіграє істотну роль в процесі змагальної діяльності. 
Опитування хокеїстів за шкалою «Витривалість» виявило середній показник самооцінки в групі - 73,7 $\pm 11,9$ бала, що також свідчить про високу самооцінку. Однак варіативність отриманих даних тут значно вища, ніж за попередньою шкалою.

Подібне розходження, на наш погляд, може бути обумовлене ступенем впливу рухової якості «Витривалість» на ефективність змагальної діяльності хокеїстів різного амплуа. Найменшою мірою від рівня розвитку витривалості може залежати ігрова діяльність хокейного воротаря, для ефективності дій якого більше потрібні блискавична реакція, вміння правильно обирати позицію у воротах тощо. Для захисників, які проводять на майданчику значно більше ігрового часу, ця фрізична якість необхідна найбільше порівняно 3 нападаючими.

Зіставлення індивідуальних показників, які було отримано за шкалою самооцінки «Швидкісні здібності», свідчить про високий рівень цієї рухової якості у більшості хокеїстів. Середній рівень у групі становить 74,0 \pm 14,2 бала. При цьому можна спостерігати досить високі діапазони відхилення від заданих (цільових) параметрів.

Серед усіх рухових якостей, за якими хокеїстам було запропоновано провести самооцінку, найменші бали було отримано за шкалою «Гнучкість». Середній рівень набраних балів у групі становить 71,8 \pm 8,92.

Наступна група якостей, за якими було запропоновано хокеїстам оцінити рівень свого розвитку, характеризувала технічну і тактичну складову підготовленості. Зокрема, спортсменам було необхідно оцінити рівень техніки переміщення на майданчику, точність кидків і загальний рівень майстерності.

Аналіз результатів проведеного дослідження за шкалою «Техніка катання» встановив завищену самооцінку практично у всіх гравців. Тут необхідно також відзначити, що під час проведення дослідження гравцям було запропоновано розглянути даний елемент технічної підготовленості в досить широкому сенсі. Окрім простого маневрування і переміщення гравців по майданчику до даної діяльності було віднесено і раптові зупинки зі зміною напрямку руху, здатність миттєво наби- рати швидкість, виконувати складні рухові дії на ковзанах, у тому числі і при безпосередньому контакті з суперником і багато іншого [26].

У результаті практично всі хокеїсти за даним показником оцінили свій рівень як максимально високий. Проте, на нашу думку, подібний факт може бути цілком зрозумілий, з огляду на високий клас спортсменів, для яких подібні маневрувальні дії не є предметом серйозного вдосконалення, оскільки кожен 3 них має стаж володіння такою навичкою від 15 до 25 років. У середньому, по групі рівень самооцінки становить 96,8 \pm 5,6 бала.

Статистична обробка даних по групі показників «Самооцінка рівня психологічної підготовленості» виявила, що за шкалою «Концентрація уваги» визначено середній рівень в групі - 72,81 $\pm 11,54$ бала.

Результати вивчення рівня прояву самооцінки хокеїстів високого класу за шкалою «Самовладання» дозволили констатувати середній рівень в даній групі, що дорівнює 73,12 — 12,09 бала.

Серед важливих показників, за якими фахівці рекомендували провести самооцінку хокеїстів високого класу, було виділено стресостійкість. Аналізуючи отримані дані, можна відмітити високий і середній рівні домагання в групі спортсменів, а також кардинальну протилежність результатів, отриманих в окремих спортсменів. Середньогруповий рівень самооцінки за шкалою «Стресостійкість» становив 72,5 $\pm 16,22$ бала, рівень домагання - 94,3 \pm 8,73 бала, а діапазон цільового відхилення - 21,87 \pm 19,05 бала.

Отримані дані вказують на необхідність акцентування особливої уваги на психологічному компоненті в процесі подальшої роботи з корекції самооцінки гравців. Дане припущення підтверджується виявленими коефіцієнтами кореляційного взаємозв'язку, які були отримані при зіставленні ефективності змагальної діяльності гравців (за інтегральним коефіцієнтом). Так, найбільш високий рівень самооцінки і домагання відмічено за компонентами самооцінки, які відображали технікотактичну і психологічну підготовленість спортсменів. Найбільш високі значення цільового відхилення було зафріксовано за компонентом «Психо- логічна підготовленість» (17,91 бала), найменші - за техніко-тактичною підготовленістю (9,7 бала). Найбільш високий рівень взаємозв'язку ефективності змагальної діяльності спостерігався за тим компонентом самооцінки, який відображав психологічну підготовленість спортсменів ( $r=0,837)$.

Проведений аналіз самооцінки хокеїстів високого класу дозволив виявити у випробуваних спортсменів середній (актуальний) і високий рівні самооцінки: середній рівень становив $74,31 \pm 6,62$ бала, рівень домагання 89,92 \pm 4,92 бала, а рівень відхилення від цільового, бажаного, результату $-14,60 \pm 3,82$ бала [26].

Не менш значущою, при детальному розгляді суб'єктів спортивної діяльності, є роль та особистісні особливості тренера. Беззаперечно в спорті тренер $€$ головною особою, яка впливає не тільки на процес спортивного вдосконалення, а й на особистісне зростання спортсмена, коли його наявн особистісні якості детермінують ступінь та швидкість оволодіння необхідними знаннями та навичками його учнів - спортсменів. У зв'язку з цим своєчасними є отримані в процесі наукових досліджень дані, що дозволили ученим [30, 39] теоретично та експериментально обґрунтувати структурну модель професійно важливих якостей тренера 3 футболу. Така модель включає компоненти, що характеризують професійно важливі якост футбольного тренера: індивідуальнопсихологічні якості і характеристики; поведінку і взаємодію; соціальний статус і освіту; зовнішність; спеціальні знання і вміння [30]. При цьому кожен 3 виділених структурних компонентів розподіляється на змістові характеристики, що в цілому складає модель професійно важливих якостей тренера з футболу. Вказані компоненти такої моделі професійно важливих якостей залежать від особистісних якостей та характеристик особистості тренера, які визнані важливими для есективної тренерської та змагальної діяльності команди [22].

До складу індивідуально-психологічних характеристик входять: мотиваційні; поведінкові; когнітивні; атенційні; моральні; емоційні; психомоторні та стресостійкість. Емоційній 
Т а б л и ц я 2. Значення вагомих емоційних якостей та стресостійкості в структурі іміджу тренера з футболу з точки зору команд різного рівня, бал

\begin{tabular}{|l|l|l|l|}
\hline \multicolumn{1}{|c|}{ U-17, $\mathbf{n = 1 9}$} & U-19, $\mathbf{n = 8}$ & \multicolumn{1}{|c|}{ U-21, $\mathbf{n = 2 1}$} & \multicolumn{1}{|c|}{ ФК «ІІахтар», $\mathrm{n}=23$} \\
\hline $\begin{array}{l}\text { Maє почуття гу- } \\
\text { мору, 2,56 }\end{array}$ & & $\begin{array}{l}\text { Позитивно налашто- } \\
\text { ваний, 2,43 }\end{array}$ & Позитивно налаштований, 2,48 \\
\hline & & & Життерадісний оптиміст, 2,56 \\
\hline & & & Має почуття гумору, 2,7391 \\
\hline & & $\begin{array}{l}\text { Стресостійкий в процесі зма- } \\
\text { гань, 2,74 }\end{array}$ \\
\hline & & $\begin{array}{l}\text { Психологічно стійкий, } \\
\text { контролює емоції і поведінку, } \\
2,56\end{array}$ \\
\hline
\end{tabular}

Т а б л и ц я 3. Значення вагомих моральних та вольових якостей у структурі іміджу тренера з футболу з точки зору команд різного рівня, бал

\begin{tabular}{|c|c|c|c|}
\hline $\mathrm{U}-17, \mathrm{n}=19$ & U-19, $n=8$ & $\mathrm{U}-21, \mathrm{n}=21$ & ФК «Шахтар», $\mathbf{n}=23$ \\
\hline \multirow[t]{8}{*}{$\begin{array}{l}\text { Наполегливий, } \\
\text { завзятий, 2,53 }\end{array}$} & $\begin{array}{l}\text { Людяний, розуміє про- } \\
\text { блеми і стан спор- } \\
\text { тсмена, 3,0 }\end{array}$ & Культурний, 2,48 & $\begin{array}{l}3 \text { повагою ста- } \\
\text { виться до колег і } \\
\text { спортсменів, 2,48 }\end{array}$ \\
\hline & $\begin{array}{l}3 \text { повагою ста- } \\
\text { виться до колег і } \\
\text { спортсменів, 2,87 }\end{array}$ & Порядний, 2,55 & Порядний, 2,55 \\
\hline & Порядний, 3,0 & $\begin{array}{l}3 \text { повагою ста- } \\
\text { виться до колег і } \\
\text { спортсменів, 2,43 }\end{array}$ & $\begin{array}{l}\text { Справедливий, } \\
\text { об'єктивний, 2,43 }\end{array}$ \\
\hline & $\begin{array}{l}\text { Дотримується } \\
\text { корпоративної етики } \\
\text { та солідарності, 2,87 }\end{array}$ & Чесний, 2,43 & \\
\hline & $\begin{array}{l}\text { Справедливий, } \\
\text { об'єктивний, 2,75 }\end{array}$ & & \\
\hline & $\begin{array}{l}\text { Толерантний, тактов- } \\
\text { ний, вихований, 2,87 }\end{array}$ & & \\
\hline & Культурний, 2,62 & & \\
\hline & Чесний, 2,5 & & \\
\hline
\end{tabular}

складовій належить 3,32 \% в структурі іміджу, до якої відносять: позитивно налаштований життєрадісний оптиміст, емоційний з почуттям гумору. Стресостійкість як складова іміджу $(5,16 \%)$ залежить від індивідуальних якостей тренера (стресостійкість у процесі змагань, емоційна стійкість, контроль емоцій і поведінки, стриманість, врівноваженість, спокійність тощо). В середньому вказані якості для всіх спортсменів не мають вагомого значення, а представлені в діа- наполегливий і завзятий, сильний духом, сміливий, схильний до ризику, рішучий, лідер. Ці якості для спортсменів усіх команд знаходяться в діапазоні середньої значущості, окрім певних якостей, які мають вагому значущість (в балах): поважає колег $(2,49)$, порядний $(2,47)$, лідер $(2,43)$ та набувають різної вагомості для команд різного рівня (табл. 3).

Дане дослідження встановило незначні розбіжності в структурі іміджу тренера, що можуть бути враховані під час роботи з командами різного рівня та віку, а саме: якщо для спортсменів юнацьких U-17, U-19 та молодіжної U-21 збірних розглянуті емоційні якості та стресостійкість не мають особливого значення, то моральні якості тренера набувають найбільшого значення саме для спортсменів юнацького віку.

Отримані в результаті кореляційного аналізу дані про відсутність значущого кореляційного зв'язку між віком, стажем спортсменів та оцінкою важливості складових показників бажаної функціональності іміджу тренера, дали підставу авторам зробити цікавий та значущий для формування особистого іміджу тренерів різного рівня профресійної майстерності висновок про його універсальність для тренерів різних категорій під час роботи з командами різного рівня та віку [22].

Поряд 3 викладеними вище чинниками, які сприяють успіху у професійній діяльності тренерів, існують і інші, що призводять до незадовільних результатів. Щодо цього своєчасним та цікавим $€$ довготривале та детальне вивчення професійного вигорання, що найбільш часто зустрічається як негативне психологічне явище у професії тренера, здійснене в наукових працях В. І. Ковальчук [16].

Специсріка ряду видів діяльності, до яких належить і спортивна, припускає проведення значної кількості часу у взаємодії з іншими людьми. Нерідко такі взаємодії насичені емоціями, більшість із яких явно негативні: злість, сором, страх або розпач. Оскільки вирішення проблеми, що виникла у процесі взаємодії, не завжди очевидне й легко здійсненне, ситуація часто стає стресогенною. За таких обставин для людини, яка постійно працює з людьми, хронічний стрес і емоційне висна- 
ження можуть призвести до особливої форми їх прояву - психологічного вигорання особистості [38].

Важливість вигорання як явища в соціальному житті людини привела до розуміння, що воно має наслідки, які не просто позначаються на добробуті людей, чия діяльність пов'язана із соціальною сферою, якості їхньої роботи, а й на стані тих, з ким вони взаємодіють [4, 8, 25].

Спортивні тренери вписуються у структуру людської сфрери обслуговування або професійної допомоги (система людина-людина) і є кандидатами на вигорання [8, 9, 14, 20].

Часте рефрормування сфери освіти вплинуло на масовість цього стану як у педагогічному середовищі, так і в інших професійних ссрерах. Це призвело до зниження соціальних, культурних, економічних цінностей і значущості тренерської діяльності як варіанта педагогічної праці. Проте готовність до безпомилкових, ефективних дій в умовах професійного стресу 3 мінімальними витратами адаптивних ресурсів можлива лише за умови профрілактики та корекції синдрому професійного вигорання. Саме тому чинники, що призводять до профресійного вигорання, важливі для досконального вивчення та формування ефективних психопрофрілактичних заходів, які сприяють поліпшенню здоров'я й надійності професійної діяльності тренера [2, 29].

У ході дослідження, в якому взяли участь тренери різних видів спорту 3 різним спортивно-педагогічним стажем, різної статі та віку, встановлено, що групи «досвідчених» тренерів і «початківців» 3 високим рівнем вірогідності вигорання різняться за стажем роботи й віком. Розрахунки свідчать, що інтегральний показник вигорання вірогідно вищий у групі «початківців» порівняно 3 «досвідченими». При цьому показник редукції (зниження) особистісних досягнень вищий у «досвідчених». У той самий час редукція особистісних досягнень у «початківців» має тенденцію до збільшення, що й сприяє їх вигоранню [17].

Як свідчить аналіз науково-методичної літератури, більшість дослідників не прийшли до єдиної точки зору в питанні гендерних відмінностей при впливі вигорання. У результаті порів- няння жінок і чоловіків у групі «досвідчених» тренерів, а також «початківців», нами не було знайдено істотних відмінностей. На наш погляд, це може свідчити про те, що особливості феномена вигорання проявляються незалежно від гендерної приналежності [29].

у процесі дослідження особистості «досвідчених» тренерів виявлено пряму кореляційну залежність між компонентами усередині розвитку процесу вигорання: емоційним виснаженням і деперсоналізацією, емоційним виснаженням і інтегральним показником вигорання, деперсоналізацією та інтегральним показником вигорання; зворотна залежність між емоційним виснаженням, деперсоналізацією, інтегральним показником вигорання і редукцією (зменшенням) особистісних досягнень. Також встановлено, що зі збільшенням показника емоційного виснаження зростає частка його внеску в інтегральний показник вигорання і зменшується частка редукції (зменшення) особистісних досягнень, а зі збільшенням показника деперсоналізації зменшується частка емоційного виснаження і редукції особистісних досягнень у цьому показнику; зі збільшенням редукції особистісних досягнень зменшується його ж частка в інтегральному показнику вигорання і збільшується частка емоційного виснаження [5].

Рівень вигорання викликаний зростанням показників фраз «Напруження», «Резистенції», «Виснаження», сумою всіх трьох фраз, високим рівнем нейротизму, зменшенням вегетативного коефіцієнта (накопичення енергетичних запасів, посилення процесів анаболічних, асиміляторних) й віку «досвідчених» випробуваних. Крім того зі збільшенням рівня нейротизму також зростають показники кожної з фаз емоційного вигорання, тобто зростання емоційного напруження $€$ тією провідною детермінантою, яка як прямо, так і опосередковано впливає на вигорання.

Проте у групі «початківців» отримано пряму залежність тільки між двома компонентами усередині вигорання: емоційним виснаженням і деперсоналізацією; інтегральним показником вигорання і емоційним виснаженням; інтегральним показником ви- горання і деперсоналізацією; зворотна - між інтегральним показником вигорання і редукцією особистісних досягнень. Виявлені дані свідчать, що вигорання у групі «початківців» обумовлене зростанням «Напруження», «Резистенції», «Виснаження», сумою усіх фраз, проявом особистісних характеристик тренерів - особистісною тривожністю, інтернальністью у сфері здоров'я, зниженням показника екстраверсії. При цьому провідними чинниками, що прямо й опосередковано впливають на рівень вигорання у групі тренерів «початківців», є висока особистісна тривожність, підвищена інтернальність у ссрері здоров'я й інтровертованість [16].

Спостерігається зміна рівня вигоряння у «досвідчених» фахівців на різних етапах їх діяльності. При вступі у професійну діяльність рівень вигорання досить високий. Далі, із набуттям фахівцем досвіду, знань, умінь і навичок професійної діяльності (приблизно до 28 років), відбувається адаптація до професії й, відповідно, зниження рівня вигорання, який потім змінюється "Хвилеподібно», залежно від того, у якому віці людина почала профресійну кар'єру [5].

Тренери «початківці» на початку кар'єри відчувають просресійний стрес, що пояснює підвищення показника інтегрального рівня вигорання. Ранній початок професійної діяльності веде до високого рівня вигорання.

У всій вибірці із накопиченням досвіду й адаптації до умов діяльності показники вигорання знижуються; надалі - зі збільшенням професійного досвіду й стажу роботи - спостерігається зростання його показників [17].

На початкових етапах становлення професійної майстерності, безпосередньої практичної діяльності саме особистісні особливості значною мірою визначають рівень і характер вигорання представників тренерських професій. Інші детермінанти, як показують дослідження, відіграють не настільки істотну роль.

Знання особливостей змін рівня вигорання протягом професійної діяльності тренерів дає можливість успішно запобігати можливим професійним кризам у житті тренерів. 
У сучасних наукових розробках відомих спортивних психологів підкреслюється, що всі напрями роботи з психологічної підготовки в команді тільки частина цілісної системи впливів, які повинні відрізнятися за формою і за змістом, залежно від специсріки виду спорту, умов організації тренувальної та змагальної діяльності і відносять до них [7, 31-33]:

- оцінку поточного рівня психологічної підготовленості (базова психодіагностика): діагностуються потенційні можливості спортсмена, домінуючі психічні стани, спрямованість поведінкових реакцій у повсякденному житті і спорті;

- розробку індивідуальної програми дій (програмування психологічної підготовки): спираючись на дані, отримані під час базової психодіагностики, складається програма комплексного впливу на спортсмена, яка включає конкретні завдання для розвитку необхідних спортсмену якостей, формування стану оптимальної готовності до майбутніх змагань;

- організацію зворотного зв'язку стану спортсмена (моніторинг і оперативна діагностика): контроль поточного стану спортсмена за допомогою методів експрес-діагностики, спостережень і бесід;

- застосування додаткових заходів (оперативна корекція): у випадках емоційного зриву, внутрішньоособистісного або міжособистісного конфлікту, стану перенапруження спортивний психолог оперативно проводить психокорегуючі або психорегуляційні впливи через створення цільових завдань індивідуальної спрямованості;

- створення адекватного психічного стану (налаштування): базується на сформованій взаємній довірі між спортсменом і спортивним психологом і дуже індивідуальних механізмах впливу, повністю довірчих стосунках. Дозмагальні налаштування спортсмена, оптимізація його достартового стану сприяє створенню індивідуального ритуалу дозмагальної і змагальної поведінки;

- управління станом спортсмена в змаганнях (секундування): через обмеженість можливостей спілкування зі спортсменом під час змагальної боротьби, коли необхідно в процесі його психологічної підготовки ссрормувати навички невербальних впливів або прийоми самовпливів, за допомогою яких оперативно відновлюється стан спортсмена;

- компенсацію негативних наслідків (відновлення): діагностика особистісного стану кожного спортсмена протягом спортивного сезону і відновлення актуального стану його психіки, звільняючи її від негативних наслідків особистісних, сімейних, офріційних і інших проблем і відновлюючи бажання почати тренуватися і змагатися, оптимальний бойовий стан;

- контроль психологічної атмосфери в спортивній команді, особливостей взаємин і взаємодій, що існують між суб'єктами спортивної діяльності, і багато інших аспектів.

Висновки. Дослідження психологічних особливостей проявів особистості спортсменів та тренерів як суб'єктів спортивної діяльності дає можливість спортсменам цілеспрямовано формувати психологічні якості, які сприяють досягненню успіхів у тренувальній і змагальній діяльності; тренерам - керувати процесом підготовки враховуючи необхідний рівень розвитку науково обґрунтованих професійних якостей спортсменів; успішно запобігати можливим професійним кризам життя тренера, з огляду на можливий негативний вплив на ефективність профресійної діяльності, та продовжувати професійне життя в спорті, знаючи та враховуючи професійно важлив якості як складові іміджу тренера.

Перспективи подальшого дослідження пов'язані 3 теоретичним та експериментальним вирішенням поставлених завдань згідно з напрямами науково-дослідної роботи.

Конфлікт інтересів. Автори заявляяють, що відсутній будь-який конфолікт інтересів.

\section{ЛITEPATУРА}

1. Бендас ТВ. Гендерные исследования лидерства. Вопросы психологии. 2000;1:87-95

2. Бойко ВВ. Синдром «эмоционально го выгорания» в профессиональном общении. Санкт-Петербург: Питер, 1999. 243 с.

3. Бриль МС. Индивидуализация в спортивных играх: трудности, опыт, перспективы. Теория и практика физической культуры. 2001;5:32-3

4. Водопьянова НЕ. Профессиональное «выгорание» и ресурсы его преодоления. Пси хология здоровья Санкт-Петербург: Питер, 2003. 186 c.

5. Воронова ВИ, Ковальчук ВИ. Особенности проявления выгорания личности тренера в процессе профессиональной деятельности. Наука в олимпийском спорте. 2016;1:46-50

6. Воронова ВИ, Смоляр ИИ. Гендерные особенности делового и эмоционального лидера в гандбольной команде. Спортивный психолог. 2011;3:43-8.

7. Горбунов ГД. Психопедагогика спорта. Москва: Советский спорт, 2012. 311 с.

8. Горская ГБ. Организационный стресс в спорте: источники, специфика проявлений, направления исследований. Физическая культура, спорт - наука и практика. 2012;4:74-6.

9. Гринь ЕИ. Личностные факторы, обусловливающие развитие профессионального выгорания у спортсменов разного пола. Физическая культура, спорт - наука и практика. 2009;1:33-7.

10. Джамгаров ТТ, Румянцева ВИ. Лидерство в спорте. Москва: Физкультура и спорт, 1983. $80 \mathrm{c}$.

11. Зинкевич-Евстигнеева ТД. Эфрективная команда: шаги к созданию: руководство для тех, кто хочет создать свою команду. СанктПетербург: Речь, 2003. 128 с

12. Зубков АЕ, Лазарева ВГ. Роль лидеров в спортивной команде. В: Фізичне виховання здоров'я студентів: матеріали Всеукраїнської наук. прак. конф. Донецьк; 2009. с. 61-4.

13. Ильин ЕП. Психология индивидуальных различий. Санкт-Петербург: Питер, 2004. 702 с.

14. Качина АА, Дайняк ВН. Специфика профессионального стресса в деятельности тренера по фигурному катанию. В: Психология психических состояний: теория и практика: материалы первой Всерос. науч.-практ. конф. Казань: 3 АО «Новое знание», 2008. с. 76-80.

15. Клецина ИС. Практикум по гендерной психологии. Санкт-Петербург: Питер, 2003. 480 с.

16. Ковальчук ВІ. Особистісні детермінанти професійного вигорання тренерів в спорті. [дисертація] Київ, 2016. 187 с.

17. Ковальчук ВІ, Воронова ВІ. Особливості професійного вигорання тренерів з різним професійним досвідом. Збірник наукових праць Східноєвропейського національного університету імені Лесі Українки: Фізичне виховання, спорт і культура здоров'я у сучасному суспільстві. 2014;3(27):15-8.

18. Кокун ОМ. Особливості професійної спрямованості, компетентності та професійноважливих якостей фахівців професій типу «людина-людина» у порівнянні 3 фахівцями професій інших типів. Актуальні проблеми психології. 2012. т. 5;12:90-8.

19. Кон ИС. Междисциплинарные исследования. Социология. Психология. Антропология. Ростов-на-Дону: Феникс, 2006. 608 с.

20. Корх АЯ. Тренер: деятельность и личность: учебное пособие. Москва: Терра-спорт, 2000. $120 \mathrm{c}$

21. Лозовая ГВ. Формирование самооценки спортсмена: учебное пособие. Санкт-Петербург: Санкт-Петербургская гос. акад. физ. культуры им. П.Ф. Лесгафрта; 2003. 20 с.

22. Малиновский АИ, Петровская ТВ. Личностные детерминанты формирования функционального имиджа тренера по футболу при работе с командами разного уровня. Наука в олимпийском спорте. 2018;1:66-72.

23. Материалы научной конференции, посвященной итогам научно-исследовательской работы за 1967 год. Киев: КГИФК, 1968. 123 с.

24. Материалы научной конференции по итогам научно-исследовательской работы за 1968 год. Киев: КГИФК, 1969. 146 с.

25. Мищенко АВ. Личностные детерминанты эмоционального выгорания спортивных тренеров [автореферат]. Сочи, 2011. 22 с. 
26. Міхнов АП. Підвищення ефективності змагальної діяльності висококваліффікованих хокеїстів засобами корекції самооцінки. [дисертація] Київ, 2017. 187 с

27. Научная конференция, посвященная итогам научно-исследовательской работы за 1956 год. Тезисы и рефераты научных работ. Киев: КГИФК, 1957. 157 с

28. XI Наукова конференція, присвячена підсумкам науково-дослідної роботи за 1958 рік. Тези і реферати наукових робіт. Київ: КДІФК, 1958. 98 c.

29. Орел ВЕ. Синдром психического выгорания личности. Москва, 2005. 330 с

30. Петровская Т, Малиновский А. Со ииально-психологические составляющие функционального имиджа тренера по фрутболу. Нау ка в олимпийском спорте. 2017;2:39-44.

31. Родионов АВ. Психология фииического воспитания и спорта. Москва: Академический Проект, 2004. 576 с.

32. Родионов АВ. Психология - спорту высших достижений. Спортивный психолог. 2008;1(13):4-7.

33. Сивицкий ВГ Система психологического сопровождения спортивной деятельности Спортивный психолог. 2007;1(9):37-42.

34. Смоляр ИИ. Дифференциация лидер ских качеств спортсменов в мужских и женских командах (на примере игровых видов спорта) [диссертация]. Киев; 2011. 192 с.

35. Смоляр И, Турчина Н. Гендерный аспект лидерства в спорте. В: Олімпійський спорт спорт для всіх: IX Міжнар. наук. конгрес: тези доповідей. Київ: Олімпійська л-ра, 2005. с. 195

36. Смоляр І. Особистісні детермінанти лідерства в чоловічих і жіночих спортивних командах. Молода спортивна наука України 2008;12, т. 1. с. 330-335.

37. Хасина ПЛ. Ролевой состав команды и динамика ее эффективности. Вопросы психо логии. 2009;4:91-98.

38. Maslach C, Jackson SE The Maslach Burnout Inventory. CA : Consulting psychologists press. Palo Alto. 1986. 209 p

39. Petrovska T, Sova V, Khmelnitska I, Bo rysova 0, Imas Y, Malinovskyi A, Tereschenko L. Research of football coach's professionally important qualities in football player's perception. Journal of Physical Education and Sport. 2020;20 (Supplement issue 1):435-440. doi:10.7752/ jpes.2020.s1063.

\section{LITERATURE}

1. Bendas TV. Gender leadership research. Psychology issues. 2000;1:87-95.

2. Boyko VV. Burnout syndrome in professional communication. Saint Petersburg: Piter 1999. $243 p$

3. Brill MS. Individualization in sports games: difficulties, experience, prospects. Teoriya i prak tika fizicheskoy kultury. 2001;5:32-3.

4. Vodopyanova NE. Professional «burnout» and resources to overcome it. Psikhologiya zdoro vya St. Petersburg: Piter, 2003. $186 p$

5. Voronova VI, Kovalchuk VI. Features of the manifestation of burnout of a coach's personality in the process of professional activity. Nauka v Olimpiyskom sporte. 2016:1:46-50.

6. Voronova VI, Smolyar II. Gender characteristics of a business and emotional leader in handball team. Sportivny psikholog. 2011:3:43-8.

7. Gorbunov GD. Psychopedagogy of sports Moscow: Sovetsky sport, 2012. 311 p.

8. Gorskaya GB. Organizational stress in sports: sources, specificity of manifestations, research directions. Fizicheskaya kultura, sport nauka i praktika. 2012:4:74-6.
9. Grin El. Personal factors determining the development of professional burnout in athletes of different sex. Fizicheskaya kultura, sport - nauka praktika. 2009;1:33-7.

10. Dzhamgarov TT, Rumyantseva VI. Leadership in sports. Moscow: Fizkultura i sport, 1983. $80 \mathrm{p}$

11. Zinkevich-Evstigneeva TD. Effective team: Steps to build: A guide for those looking to build their team. St. Petersburg: Rech, 2003. 128 p.

12. Zubkov AE, Lazareva VG. The role of leaders in the sports team. A: Physical education is the health of students: materialy Vseukrainskoi naukovo-prakt. konferentsii. Donetsk; 2009. p. 61-4.

13. Ilyin EP. Psychology of individual dif ferences. Saint Petersburg: Piter, 2004. 702 p.

14. Kachina A.A., Dainyak VN. The specifics of professional stress in the activities of a figure skating coach. In: Psychology of mental states: theory and practice: materialy Vseros. nauchno-prakt. konf Kazan: ZAO «Novoye znaniye», 2008. p. 76-80.

15. Kletsina IS. Workshop on Gender Psychology. Saint Petersburg: Piter, 2003. 480 p.

16. Kovalchuk VI. Personal determinants of coach professional burnout in sport. [dissertation] Kyiv, 2016. 187 p.

17. Kovalchuk VI, Voronova VI. Features of professional burnout of coaches with differen professional experience. Skhidnoievropeyskyi natsionalny universytet imeni Lesi Ukrainky. 2014;3(27):15-8.

18. Kokun OM. Peculiarities of professiona orientation, competence and professionally impor tant qualities of specialists of «human-human professions in comparison with specialists of othe types of professions. Aktualni problem psykholo hii. 2012. T. 5;12:90-8.

19. Kon IS. Interdisciplinary research Sociology. Psychology. Anthropology. Rostov-onDon: Feniks, 2006. 608 p.

20. Korkh A.Y. Coach: Activity and Personality: Study Guide. Moscow: Terra-sport, 2000. 120 p.

21. Lozovaya GV. Formation of an athlete's self-esteem: a textbook. St. Petersburg: Sankt-Pe terburgskaya gos. akadem. fizkultury im. P.F. Lesgaft; $2003.20 \mathrm{p}$

22. Malinovsky Al, Petrovskaya TV. Persona determinants of the formation of the functional image of a football coach when working with teams of different levels. Nauka v Olimpiyskom sporte. 2018;1:66-72

23. Materials of the scientific conference dedicated to the results of research work in 1967. Kiev: KGIFK, 1968. 123 p.

\section{ІНФОРАМАЦЯ ПРО АВТОРІВ}

Воронова Валентина Іванівна https://orcid.org/0000-0002-5072-4184, professor.voronova@ gmail.com

Петровська Тетяна Валентинівна https://orcid.org/0000-0003-3936-1965, petrovska.tetiana@ gmail.com

Ковальчук Вікторія https://orcid.org/ 0000-0002-7969-3959, kovalchuk.v.i@ukr.net Смоляр Ірина Іванівна https://orcid.org/0000-0001-8817-7035, rusiksmol@gmail.com Національний університет фрізичного виховання і спорту України, 03150, Київ, вул. Фізкультури, 1

\section{INFORMATION ABOUT THE AUTHORS}

Voronova Valentyna https://orcid.org/0000-0002-5072-4184, professor.voronova@gmail.com Tetiana Petrovska https://orcid.org/0000-0003-3936-1965, petrovska.tetiana@gmail.com Kovalchuk Viktoriia https://orcid.org/ 0000-0002-7969-3959, kovalchuk.v.i@ukr.net Smoliar Iryna https://orcid.org/0000-0001-8817-7035, rusiksmol@gmail.com

National University of Ukraine on Physical Education and Sport,

03150, Kyiv, Fizkul'tury str., 1. 